\title{
<会長対談 $>$
}

\section{学びたい心，究めたい心}
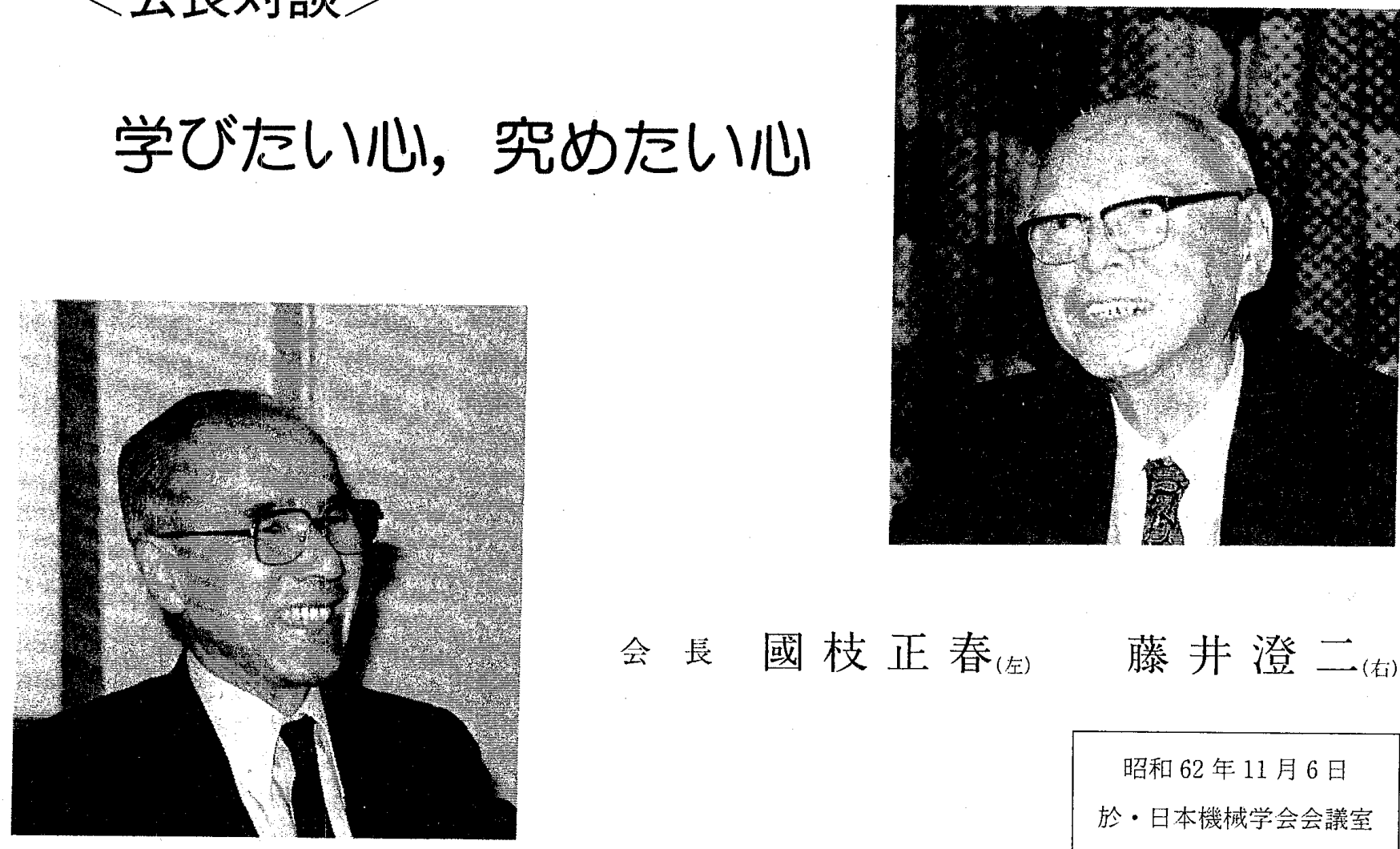

会長 國枝 正春(左) 藤 井 澄二(右)

\section{1. 機械工学を志したいきさつ}

國枝きょうは「学びたい心, 究めたい心」とい うのをテーマとして，先生のご意見をうかがわせてい ただきたいと思います。この主題については，教える 立場の教育者と，教えら机る立場の学生とで心構えが いくぶん違うとは思いますが，そこまでは踏み込まな いで，とにかく人間の心構えとして，それがどういう ものなのか浮び上がらせることができ扎ばと思って 㧈ります。

先生がこの問題に関連して，平素心に持持ちのこと をお聞きしたいと思います。

まず最初に，先生が機械工学安志したいきさつとい うところから扮話し願えますでしょうか。

藤井この辺は大変恥ず沙しいんですよ。私は子 供のころから割合自然科学柔の学者になりたいという 気持ちは持っていたんです。

高等学校の理科を卒業して大学入行くという時点 て，何虏專門にしようかということを考之たとさに は，ぜひ懴械工学家やりたい上思ったわけではなく， できれば物理䘮やりたいと思ったんです。しかし，私

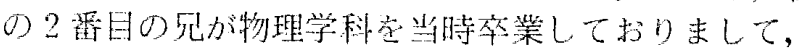
同じこと孛やったのではいつまでたっても元に抑光ら 机る，少し椲ったこと，しかも自分の能力でできそう

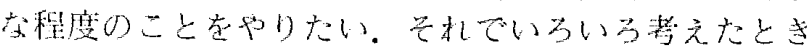

に，当時だと機械工学といっても，弾性論，流体力 学，そういうふうな基礎的なこともかなりや扎る。た とえ才能が十分でなくても後で何かにはなれるだろう という程度の，非常に安易な考え方で機械工学科へ入 つたわけです。

だから，機械工学を志したというのは非常に大きな 強い理由があるわけではなくて，觔強し始めてみて， まだいるいるやることがあるというようなことで，だ んだんと興味を持ってきた打けですね。

特に私は大学へ入ってから流体力学が好きになりま して，大学の 3 年のころに，テイラーという人の，回 転二重円筒の中に渦ができる、ドーナツ形の瀜がたく さん並んでできるという論文に接し，そ机まで流体力 学の中で安定の問題というのはほとんど报执扎ていな かったので，ぜひ，将来この流体関係の安定閶題在奶 りたいなと思っていたのです。

そのような⿰けで鈴木茂哉先生のもころで棸業設

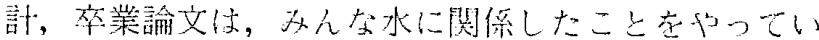
ました。ところが，古る日突然鈴木先生が，当時の比

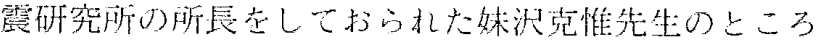

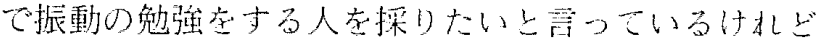

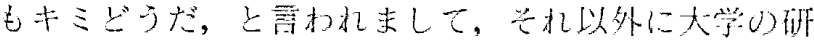

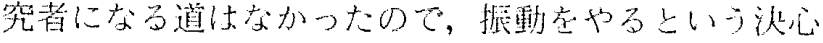
空したわ材で。

ところが，契際にはどうだったかというと，秋人人

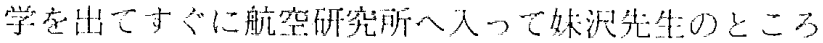


で勉強するという予定だったんですけ机ども，戦時中 ですから; 大学を卒業してすぐ兵隊にとら机て，当時 の短期現役というのに通って, 立川の航空技術研究所 に配属されました。

そういう枋で，振動をやるということはしばらく できなくて，飛行機のエンジンのタービンスーパーチ ャージャの研究を 3 年間拈らされて, そして戦争が終 わった机です。そのため機械工学を志したいきさつ とけうことになると, 余りはっきりとした, 皆さんの 参考になるような理由というのは述べられないのです 5.

だけれども，機械科の学生には割合にそういう学生 が多いみたいです权。機械が大好きだという学生もも ちろん大勢いますけれども，何をしていいかわからな いから機械科へ来たというのも結構いるみたいです 上.

國枝学うすると, 先生は最初流体力学に興味を お持ちになり，やがて振動学に移ら机たことになりま すが，これは外からきまってきたというわけですね。

藤井流体力学をやりたいと思ったときには自発 的なんです。ところが，その後で振動学や陸軍の研究 所ではタービンスーパーチャージャをやりなさいと言 わ机たりしたのは，い执ば他立的なものです。そうい う枠組みの中でもっていろいろ勉強してきた。逆に言 うと，そういうふうなものでも素直に受けとめて勉強 寸るということは，今から考えてみると非常にいいこ とだったと思うんです。そ机だけ自分の場が広くなる し，乬机ら物の考え方にフレキシビリティができて

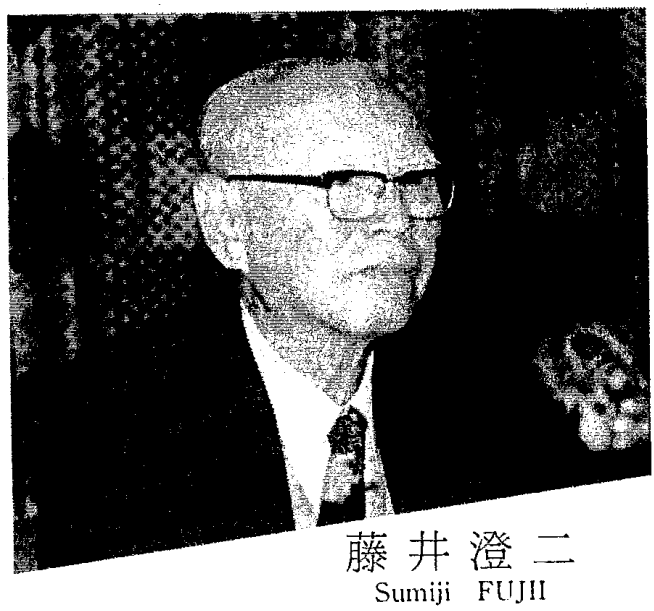

大桭 9 年 12 月 14 日生

○サージング現象，并に上る゙振動，压縮機管

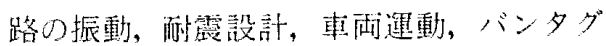
ラフ架線系の振動，人間工学，墳于烟门制 御，ロボット工学などつ研究に往事。

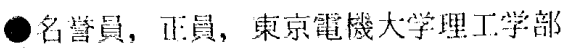

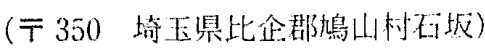

きます权，自分の専門だけで非常に狭く考えないで， いつでもいろいろなフェーズで考えられるということ です极。

國枝私の場合は，学生のころ機械科の課目のう ちにはっきりした好みがありました。やはり数学や物 理学のような解析的な学問が好きだったのでしょう 才。数学，物理学にいちばん近い課目は何だろうとい うことで機械科の課目をならべて考えて見たところ， 機械力学というのが微分方程式がそのままき机い入 ってくるということで気に入りました。私たちの学生 時代は戦時中ですから，機械力学もあまりちゃんと習 わなかったのですが，私自身は，当時，ほかの課目に 比べとても気に入って，こ扎にほ机込んな゙わけです。

そ机以来, 私の方では一生懸命ほれ続けた加けでし て，機械力学の方は私のごとをあまりほれてくれたと は思いませんが，それでも何とかこうやって，一生， 飯が食えてきたのですから，まあよかったんだろうと 思います。

勤め先の研究所にいる若い人で, 自分が何をやった らいいのかきまらないというて相談にくることがあり ます、私は，そういうとき，それはきまるのではなく てきめるのだと言い続けています。あなた自身が一生 懸命になってある専門分野にほ机てごらなさい。そ うして一生䀣命やってゆくうちに自然に道が開けるの ですと，もちろん企業の研究所ですから，問題はよ゙し どし与えられますが，やはり自分の中心的な学問分野 は，自分がそ机を中心にして生きて行くのだとう思 いつめた気迫を持つ方が意気が上がり，興味も増しま す。だから，若い人にはそういうやり方のほうをすす めているわけです。

もちろん，こ扎とは別に，先生がい打机ように， 非常に順応的に物を考え，与えられた条件の中でいる いろ自分の興味を拡大してゆくというやり方もあるこ とは知っています。

藤井外から他動的にいろいろな問題が飛び込ん できて，そ扎をいろいろな理由でもって引き受けざる を得なくなって，そ机で結局，割合にいいことになっ たなあと思うようなことが多いです权。

國枝をうでしょう极。たた，私の場合は，振動 が好きだといって，苩の国鉄の研究所にとつていただ き，次に不川島播䄷重工の技術研究所に移つたとき も，搌動屋だということでをりまま採䐐して下さっ た。要のために，振動に関して問題が起きると私のと ころに策まる扒けです。振動の中には流体に関連卞る ものがでてきたり，熱に関連するものがでてきたりし ますが，とにかく，機械力学という中心圭一持っこ いら扎たことが私には桲いしたと思っています。

ですから，私は毎日，研密所に通うのが大裂楽し、 思っています。学校と避って, 問題のうがよ゙んどん集 まってきま寸。週に2 件や3件はたちまち重なつてき

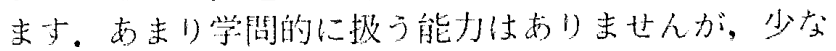
くとも勘だけは次第にするよ゙くなってい主ます。

私の場合の上うに，等間の入り口のところで，自分 
の好きなものは何だときめるやり方もあるのではない かという気がします。

もちろん学問全体に興味を持ち, 順応していろいろ な問題を扱ってゆくというのは幅を広げるという意味 ではいいでしょうね。特に先生は流体，振動と機械力 学，さらに制御，ロボットと進まれましたが，そ机ら にいつも食欲を持って食いついて㽖机たから，結局 大きな成果をあげられることになったのだと承知して います。

藤井出さ机た料理は楽しんで食べなくちゃいけ ないということでしょうか—.

\section{2. 学びたい心一学問地図論}

國枝私は企業の研究所に長年勤めていますが, 企業のお許しをもらって 2,3 の大学で振動学や機械 力学などの講義をすでに 20 年以上担当させていただ いております．学校では講義の方法にいろいろの工夫 をこらして，たとえば振動するおもちゃを使うなどや って見るのですが，どうも学生が乗ってこない。市な り努力しても効果が乏しい．特に多人数教育になる と, 大半の学生を講義に引き込むということはまこと に困難だという経験を繰り返しています。

考えて見ますと, 問題は講義を聞く側のインセンテ イブの強さに西り，聞く方に「求める心」が必要だと いうことになります，いま，いろいろと機械科のカリ キュラムに工夫を加える動きが各地の学校でなさ机て いますが，教育の実効をあげるには学生側に「求める 心」を出させることがまずたいせつだという気がしま す.

もちろん，学生のうちの食欲のない者は切り捨てる という考え方もありますが，でき机ば大半の人に食欲 を出させるようにして食物を与える方が本当の栄養に なるはずだと考えます。その「求少心」「学びたい 心」を育てるにはどうしたらよいかという問題につい て先生の考えて扔ら机ることがありましたら扔願い致 します。

藤井＼cjkstart私はいろいろなことをやらさされていて，例 えばバンタグラフのことをや扎と言机机て，國枝先生 と多分同じ委員会に出ていたんじやないかと思うんで すけ机ども，なかなか理解できないんです。とにかく 1 年くらいじいつと，ああでもないこうでもないと (私はもともとパンタグラフの専門家じゃありません でしたから), 皆さんの議論を聞いて，やっとだいた いどういうことなのかなということがわかってくるん です权，だけ扎ども，弚の間に自分で，こういうこと はどういうことなんだろうと思って，扐かたいとい う気持ちは確かにいつでも持っているんです权。とに かく㐫でもない，こうでもない上一生賏命話を聞き ながら考えている。㿝して1年くらいたって突如とし てわかったような気がし始めるんです权。

だから、どういうんでしょうか,「学びたい心」と いうのは，子供のとき加ひとりでに气ういうふうに
なってしまったのか，あるいはこういうことは湌成で きるのかどうかよくわかりませんけ机ども，私として は，こ机はどういうことなのか，何とかして自分に納 得いくような理論をつけたいというような気持ちは物 事に出会うたびにあるんですけ机ども权。

國枝 先生は本質的に学者, もしくは研究者の素 質が大変高いのです权.

藤井 いえ，そんなことはありませんけ机ども 权.例えば脱線の問題なんかでもなかなかわかららな んです权、会議のたびに試験のデータを見せていただ いているでしょう。そ机を眺めているうちに突如とし て一一同じ線路で試験をした何台もの貨物列車の振動 の記録を見ていると，違うといえば違うけ机ども，だ いたいみんな同じなんです权。そうするとこ机はかな りはっきりした力学的なモデルというものをつく机る はずだという自信をそこで持ったんです。ああいう委 員会に 1 年くらい座っていて初めて思い至るんです ね. それで初めて脱線のシミュレータをつくってみよ うというようなことを考えつくんです权。

そこまで到達するまでに非常に時間がかかるんで す.

國枝俗な言葉で申しますと，先生はやはり食欲 がおう盛なのですよ，そ机にずっと食いついていこう という，その食欲がどうして出てくるかというのは素 質なんでしょう权。もしそうだとすると，余り食欲の 湧かないのは，例えば大学は無理だとか……（笑)

藤井だけ机ども，一方ではある程度学生に食欲 を涌かさせるということは必要です权。何か教えると

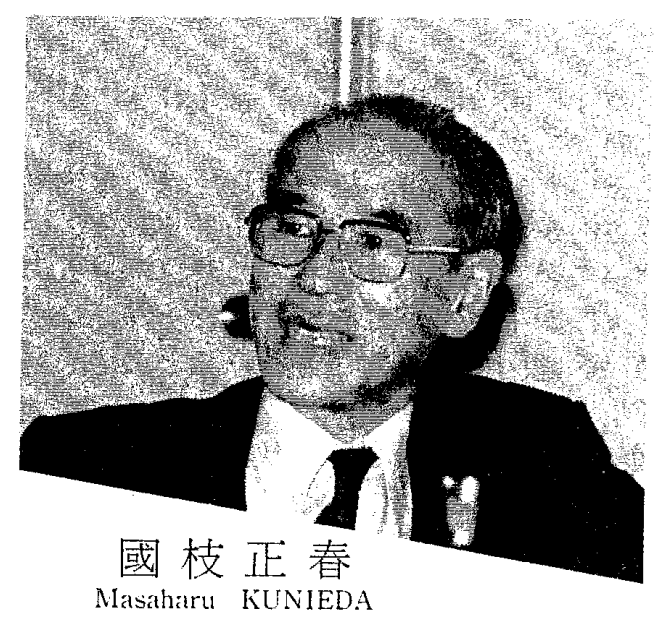

大佦 14 年 1 月 1 日生

鉄道車雨け動力学，游报，特に空氛ばねつ

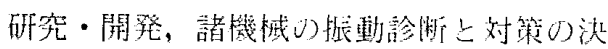

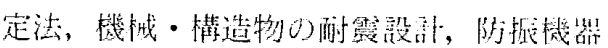

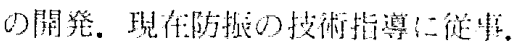

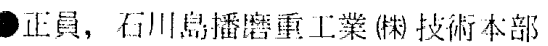

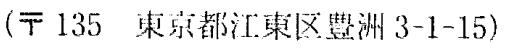


きに，実際ある程度目標といいますか，見通しという ものを持たなければ——例えばコンピュータを教え る. FORTRAN そのものを頭から教えていくという ようなことであったら，本当に砂をかむようなもので す.け机ども，それでもって何かおもしろいことがで きるんだということにな机ばかなり気持ちが違ってく るんです权．何でもいいから逃げたいと思うのと，何 でもいいからこ扎をものにして㧍もしろいことをやっ てやろうというのとでは随分違います。

そういう意味では，講義や何かでも，私は常に見通 しというか，先の方でどうなんだ，そ机から，こうい うふうなことを理解することによって, 普通常識じゃ 意外だと思わ机るようなことが，非常に素直に当たり 前なことだというふうに理解されてくるんだというこ とが納得さ机てくると, 学生の方でも興味が違ってく ると思いますが权。

しばしば言われるんだけれども，例えば数学，ある いは機械で熱力学とか，そういうふうなものを習って いても，これは一体何の役に立つんだかわからなく て，それでつまらないというようなことを低学年の学 生はよく言っておりましたけ机ども极。

國枝先程も申し上げましたが，私は学校を卒業 後，国鉄の研究所に勤めましたが，その 3 年後に大き な病気をしました。人間がはじめて障害にぶつかる と，そ狆からの人生を思って迷うものですが，そのと き私は学問だけがいちばん信頼ができると思うように なりました。

世の中で人が生きて行くにはいろいろ不安がありま 寸ね。この不安は自分の置か扎ている位置がわからな くなったという不安に同じだと思うのです。私は，そ の時から「学問地図論」という説を心にいだくように なったのです。

人生というのは一つの旅である，旅には地図を持つ ていることが非常な安心感を与えてくれる。いろいる の人がいろいろに教えて下さるのだけ扎ど毛, 結局, 昔から人間が積み上げてきた学問こそが，いちばん， 人生の旅の地図になるのだということに思い当たった わけです。

地図のむる人生は安心であり，自分の現在の位蹎を 知るここができ，また目的地に達する道を知ることが できる枹でここで，学問の意味意自分なりに悟っ た気になりました。

結局人生に扔ける安心感が得り机，名らに社会に刘 し貢献与る道己放かるわけで,こ机が学閭の非常にた いせつな意味だと扔ってから，私の「学びたい心」 の動機付けができた机です，兴机からは，私の上こ ろに来石学生さんにはそのこ上を教えるし，特に病気 したり，挫折した人たちには強く言う上うになりまし た。人間は一生，生きていかな机ばならない。关こ

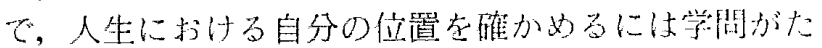

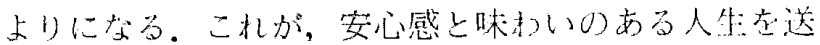
るための兔学の意昧たを。

藤井非常にいいと思いますが，嵄流にきれいる
け加えると，末知の土地を歩き回って，新しく地図を 広げていこうじやないか，そういうことがもう一つあ ると思うんです权。

國枝まさにその通りで，当時私もそう思いまし た。この学問地図論は機械学会誌の昭和 61 年 1 月号 に「こ机からの技術者の生涯教育」という文章の中で も紹介させていただいていますが，今，先生がい机 たことがその通りに書いてあります。先生のご同意が 得ら扎た扒けで大変ありがとうございます。

諸先生の中にはノ一ベル文学堂作品とか「歎異抄」 「正法眼蔵」などを学問の出発のよりどころにしてお られる方もあり，そ机它読屯ことを，先生も抢すす めになっておられることを存じています。工学は人間 と関係が深いのですが，どう関係すべきかを考えるこ とは非常にたいせつであり，こ机が，結局は工学を学 びたい心の基礎にもなるうと思っているわけです。

藤井いろいろな意味で幅を広くして㧍くという ことですね。

幼稚な例えだけれども，ヒマラヤへ登りたいという ことになれば，そこへ到達するためには，地図もいる し，そ机からパスポートとかビザとか，いろいろな手 続もいるし，そういうものを全部きちんとまず押さえ ていかなくちゃならないわけです。长机からわかって いるところの経路です权，并机が先生の言扎る「学 びたい心」で，そ机から後の未知の部分，だれもやっ たことのないような部分があって，そこが「究めたい 心」ということでしょうかね。

だから，究めるためにままず学ばなけ机ばなない 放けです权，その準備としてね。关の場合に，例えば ヒマラヤに登りたいとか何とかという目標があ机ばそ 枕だけことをするのも余り苦にならない.

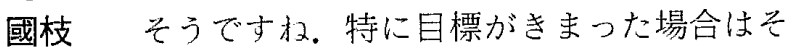
うです权，ですから地図はなるべく広く，なるべく多 く持っている方がよい，私などは手持ちの地図が少な くてまだ心細い次第です。

\section{3. 学者を志したいきさつ}

國枝先生はいつから学者圭したのですか.

藤井私は何上なく学者になるうと思っていたの です权。ただ，学者にな机のかどうかというのはい つも非常に不安なのですが. どうもよ゙さか自分の力が 非常に脆い上うな気がするのです。

國枝はなから見兮と，脆いところなどまったく 見当的ない上うに御見うけしますが。

ところで，先生は学者としてい最終的な片向につい

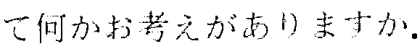

というの大，たしえば，いま主動制御で最適值問题

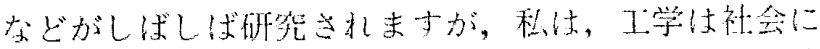

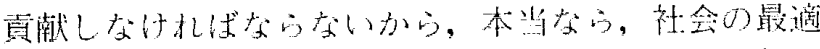

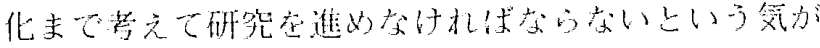
して孚り过人か。

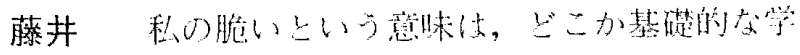


力が不足しているような気がするんです扫，何か少し 勉強し足りないところがあちこちに残っているような 気がしてね。

國枝勉強ということについていえば，私は常に 二鬼を追ってきてしまった。二兔というのは，一つは 企業の必要とする技術，他は純粋の学問です，企業と いうのは，きわめて人間くさいところがあります。と にかく利益をあげなけ机ばなりません。そういう短視 野の問題を扱いながら，一方で学問にもあこが机，そ ういう意味で二鬼を追ってきたわけです.

さきほど先生がいわ机たように，本当の学問にもあ こがれたけ机ども，それを利用する技術沁も興味があ った. 先生は理学と工学の二息に興味を持っておいで のようですが，私のは工学と，利益のあがる技術の二 鬼に興味があるということで，方向は $90^{\circ}$ 位違ってい るようです。

私は，工学や技術の評洒は最終的に人間がするもの だと思っているものですから，人間に興味が深いので すね. そして，その人間社会にどうしたら貢献できる のだろうと考え続けています。

ところで，技術者というのは，「自立・貢献・生きが い」の三つの軸を持って生きることがたいせつだと思 つています。人間は自立して行くことがどうしても必 要だけれよ゙も，自立だけでは十分でなく，貢献もしな け机ばいけない，そのとき，生き生きと生きられない のでは面白くないから，やはり生き甲斐という軸もほ しい. 生きがいは自分の職業の中で持ってもいいし, 別のところに持ってもいい.

先生のように，学問することに興味が抢ありで，そ 机が生きがいであれば，こ机ほど素晴しいことはない 上考えます。

藤井 私はどっちかというと，今までいろいろな 問題を手がけて，ほかの人から見机ばそれは仕事であ るかもしれないけ机ども，私自身にとってはこれはあ くまで道楽なんです。だから，例えば振動の問題なん か会社で起こると大変なことでしょう。ところが，私 の方にしてみれば，その相談を受けてしばらく考え て，うまく解決がつくとすごく挡しろいんですよ 权。

國枝を机恔そうですね，世の中にはいくらでも 間題がありま寸加的。无ういう生きた問題の中から 学問在捄めになることはすばらしいことだと思いま 寸。本当の産学協同というのはそういうことで進めら れるとよい扎で，機械学会などが場を提供するシス テム等広げるとよいでしょう极。

\section{4. 究めたい心（研究したい心） 一美しさへの願望-}

國枝先生の場合は問題が目の前に市札ば，探求 心がよ゙こまでも繶くのでしよう权。

藤井重瑟な現象で，何か自分に上って紏得のて きないようなことというのはすごく螊なんです。だか ら，微底的に自方自期が納得できるとこるまでは考文
てしまおうということはありますね。

國枝 問題が解けないのは苦しいですから权。它 れも不安からの脱出の願望のあらわ机とすると，ちょ つとネガティブないい方になりますが.

藤井苦しさというか, 例えば何かかゆいような 感じとか，そんなふうなものがあるかもしれないです 小.

國枝研究したい心に関連して，私には昔から 「美しさへの願望」というのがあるのです。私は生来 音楽が好きなのですが，たとえばショパンのピアノ曲 を聞いていますと，まず導入部がありますが，やがて 非常に人の心を打つところが出て来るのです权。穴机 がすんでやがて終曲になってゆくわけです。昔から人 の心を打つようなすぐれた研究論文というのは，どこ かそういうところを持っているように思います。初め から終りまで一様なのではなくて, どこか, 要するに ビューティフルなのです权。 そ狆がある研究がすぐれ た論文にもなると思うのです。

だから，私など，学者ではありませんが，何か研究 的な報告を書くときには，何となくショパンの名曲な どを頭に浮かべるのです，それで，導入部から始め， どこかにビューティフルなところを作ることを意図し て進めるわけです，研究も美しく解きたいという気は 強いですね。

藤井 ごく普通の意味の書き方ということできれ いだというのではなくて，考え方の中にすごくきれい なものを入れてほしいです权。

國枝长うですね。水。本人はあまりビューティフ ルといわないけ机ども，アメリカの連中はこの研究は ビューティフルだということをよくいいます极，確か に有限要素法などでごしごし解いただけという研究は あまりビューティフルではなきそうだと思います。

藤井 あまり力づくではない方がいいです权。

國枝なるべく難しい方法を使わなくて解けるな らその方が美しいですね。

藤井を机から私はもう一つ，論文を書くとき に，多玑少なか机，今までの人の考え方から寸的ば 意想外のものをある程度含んでいないとおもしろくな いような気がします权。

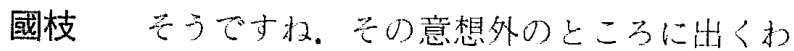
して，皆さんが强い衝牶や印象を受けることが必要な のですよ．次のベージに何が書か机ているかが想で きるようなのでなくて，心空打つところ，琴線に触 机ところがほしい机けです极。それこそ，ショパン の曲などには，とても意外な㘿が出てきて，气扎がま た大翌な味小いなのですね，意想外に，一つだけ離机 た音が人の心圭引さつける。そういうところは学問に もあって上いという気がしますま。

別の話になりますが，管めたい心については，ほか の研究者に上ると山登りの心境上いう方が扔られま す. 登るのはつらいけれら゙も，頂上に青いたときのこ

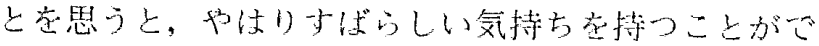
きるというものです。 
藤井 考えて，いろいろのことをやってみて，登 っていくうちに，だんだん次の峰が見えてくるという 故。そういう感覚はあります孙。

國枝そうですね，上ってみたら実の頂上は隣り の山だったとかいうことがあるのは当然でしょうね. そこで，苦しいけ机ども，もう一度元気を出して向こ うの峰に行って見ようと，そういうことなのでしょう 权.

いず机にしても，先生は非常に探求心が旺盛でいら つしゃいまして，本質的に研究者の素質をそなえてお ら机，私は素材としてはるかに劣ることを強く感じま す.

\section{5. 若い人にすすめること}

國枝最後に，若い人にすすめる言葉というのを いただきたいのですが。

藤井若い人に奨める場合に，先ほど先生が，私 のところから優机た多くの研究者が出たというような ことを抢っしゃいましたけ扎ども，私の方から言え ば，非常に優机た素質の人が集まってきたということ が事実なんです。ですから，当然優机た研究者として 出ていく.

ところが，実際その人たちに私は何かを教えたかと いうと，ほとんど何毛教えていないんです．じゃ何を したかというと，私としてはとにかく，せっかくいい 才能を持っているのを菱縮させたり壊しちゃったりし ない上うにするということ，そ扎が私の仕事だったと 思うんです。とにく自信を持って伸び伸びとやって くださいと言うんですね。

私は下手すると萎縮させちゃう面があるんですね。 私は，何でもいいからやってごらんなさいということ 在絶えず言っていたんです。こ扎やたたと言うか ら，じゃやってみなさいと、これやりたいと言うと， それもまたやってみなさいと。とにかくよ゙んよ゙んアク ティブに，理論ならもちろん金も食わないから躊躇し ないでやってい扎ばいい拈けで。

それから実験的なことでも，すごい金在使わない限 bは，とにかイ仙たいと言ったら，おってみなさい と、やってみてを机でしじったらしくじったでまた

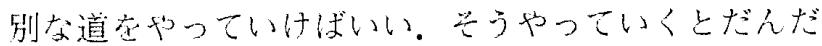
んとテタティブに物事座扔名うになった。どつちか というと，いい苗をいい烟に植えて，抢とはとにか人 伸び伸びと成長してもらう，厉ういうこは私は意識 してやってきましたけ扎ども，何か度教えたり，本当 に指導したり，引の張って伸ばしたという5うなとこ るはないて寺。確加素質のいい人が大教入ってこら 枕といのことは整策だと思いますね。

國枝素留けいい方がたくるん集末ってきたとい


るへ行导たがったのだ思います。

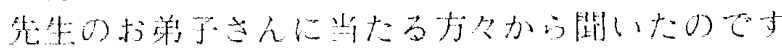

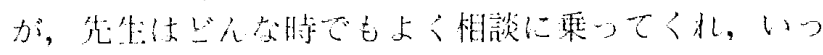

しょになって考えてく机たということで，これを皆さ んが非常に感謝しておられます。

私は，私自身にもいいきかせ，勤め先の若い人にも 言う言葉があります。それは「研究者はみだりに忙し いという言葉を使うな」ということです。研究者が相 談を受けたとき「今，自分は忙しい」と言いたくなる のですが，一般に研究者が忙しいと言うとき，しばし ば自分に能力がないと言っているのと同じことがある ような気がします。

少し㛜しいのですが，私自身にはそういいきかせて います。忙しけ札ば忙しい時間の中で，相談を受けた 問題について何らかの自分の知るところが言えるはず だと思うのです。結局「忙しい」という言葉で自分の 不勉強をかくそうとしていることが多いです权．だか ら，他の問題で忙しいなどとあまり言うべきでなく， たとえ 5 分間でも，私はこう思うとか，この問題はこ う扱うべきだと言える研究者が本物だと思うのです. 5 分しかないなら 5 分で，1日あるなら 1 日で言える こと，できることがあるのだから，忙しいという言葉 は使うなというわけです。

そういうことを含めて，先生がよく扮弟子さんの相 談に乗り，いっしょに考えて下さったということは， 私が申し上げるのは失礼ですが, 先生は研究指導者と しても高い素質を㧈もちであるということでよろしい かと思います。

藤井いい指導者であったかどうかというのはは なはだ自信がないですけ机どもれ。

國枝 そのことについては定評がございますし .....

ほかに，特に若い人に奨める言葉ということで，何 力........

藤井 ごくごく平凡なことだけ扎ども，とにかく 後でいい報いがあると思って，まず基礎的なことはし つかり勉強しなさいと。将来の活躍のために权。それ からもう一つは，仮に本や何かで勉強したことであっ てももう一遍咀嚼して，自分で考え直して，そして新 しい分野のことでも遅疑迹巡しないでよ゙んビん勉強し ながら成長していくということが必要じゃないかと思 います木.

とにかく習ったことしかおらないというんじゃまっ たく進歩がないんで权，絶えず自分自身を教育しつつ 進歩していくということ极，そこで初めて成長がある。 凡で......

國枝 かつて先生ご自身からうかがったことです が「一日でいちばん嫌だと舁うこと莮いちばん先にけ

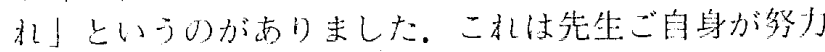
きれているということで教小ったと思っておりま与。 確かに嫌なこ上は後回しにしたくなるのだけれら゙も，

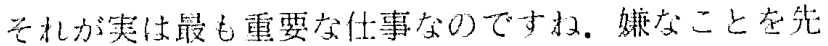

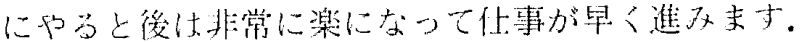

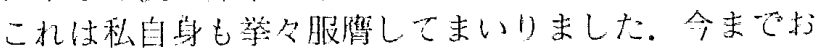

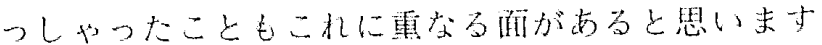

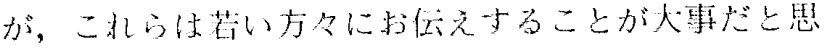


います。

藤井曾野綾子さんが『戒老録』というのをお畫 きになったんですけ机ども，それを読んでいたら，そ の中に, 年を取った一つの証拠として, 新しい機械を 使うのが非常におっくうになると書いてあるんです ね. 特に学校を出てから年がたつに徉って，新しい機 械とは言わなくても，新しい学問とか技術みたいなも のがどんどん出てきます权，例えばコンピュータが出 てくる。そういうふうなものに絶えず食いついていく だけの好奇心というものを持ち続けていないといけな い，そういうことはありますね。

國枝 その点でも先生には断然，そういうことに 探求心と素質が扔ありなのですね。. 私は何かやろうと 思うと「何のために」という理由をはっきりさせ，よ く理解してから前に進むという手続きが必要なのです が.......

藤井 例のミニコンが初めて世の中へ出て私の研 究室に入ったころに，私のところに当時いた井上博允 さんがアセンブラを使ってロボットを動かすことをや っていたんですよ，私は自分のところの学生が使って いるのに私がそ扎を使えないんじゃくやしいから，ア センブラの勉強を始めて，ちょつとした簡単なプログ ラムをつくっては動かしていたら, 井上さんが大学院 の学生だったんだけ机ども, 先生はこんなつまらない ことをやらなくてもいいんです，もっと大局的に，ど ういう方向に行ったらいいということだけ言ってく机 ればいいんです，と言わ礼てまいっちゃったんですけ 机ども，そ扎でも内緒で少しずつやっていたんです。
仮に私が大局的な方向を示すというのが仕事である にせよ，コンピュータがどう動くのか全然わからない んじゃ，こ机はどうしても気が斉まないのですよ。

國枝そうです权。人間の頭には，かなり多立の 事象をつめこんでもなおたくさんの余裕があるそうで すから.もっとも私くらいの年になると，新しいこと を覚えてもすぐに抜けて行ってしまうという大問題が ありますが。

藤井私は東京大学を定年でやめて今の東京電機 大学に移ってから，自分の部室にマイコンを持ち込む ということができて自由に使えるんで大分欲求不満か ら開放されたんですよ。

國枝ますます楽しく学問をお進め願えるわけで す权.

藤井さっきの兽野綾子さんの本じゃないけれら゙ も，いくら年取っても，新しいものに興味を失うよう になったらもう扎しまいだと思わなくちゃいけないな と思っているのです.

國枝私は最初に少し理屈を考えて，やはりこれ はいるなと自分に言い聞かせ，そ机から上うやく手を 出すという次第で, 栄養を取らなけ扎ばいけないと思 つて飯を食べるというスタイルなんです，反応が遅れ がちである点は反省します。

本当は先生に教えていただくことがもつともっとた くさんあるのに，私が少ししゃべり過ぎて時間が足り なくなってしまいました。本日はどうもありがとうご ざいました。 